\title{
Emotional labor in pediatric nursing considering the repercussions of covid-19 in childhood and adolescence
}

\author{
O trabalho emocional em enfermagem pediátrica face às \\ repercussões da COVID-19 na infância e adolescência \\ Trabajo emocional en enfermería pediátrica en vista de las \\ repercusiones del COVID-19 en infancia y adolescência
}

\author{
Bruna Hinnah Borges Martins de Freitas ${ }^{a}$ \\ Ana Inês Lourenço da Costa ${ }^{b}$ \\ Paula Manuela Jorge Diogo ${ }^{b}$ \\ Maria Aparecida Munhoz Gaíva ${ }^{a}$
}

\begin{abstract}
How to cite this article: Freitas BHBM, Costa AlL, Diogo PMJ, Gaíva MAM. Emotional labor in pediatric nursing considering the repercussions of covid-19 in childhood and adolescence. Rev Gaúcha Enferm. 2021;42(spe):e20200217. doi: https://doi.org/10.1590/19831447.2021.20200217
\end{abstract}

a Universidade Federal de Mato Grosso (UFMT) Faculdade de Enfermagem. Cuiabá, Mato Grosso, Brasil.

'Escola Superior de Enfermagem de Lisboa, Unidade de Investigação \& Desenvolvimento em Enfermagem. Lisboa, Portugal.

\section{ABSTRACT}

Objective: To discuss the emotional labor in pediatric nursing considering the repercussions of COVID-19 in childhood and adolescence.

Method: Reflexion based on theoretical aspects and scientific evidence of emotional labor in pediatric nursing.

Results: Given the repercussions of COVID-19 on children and adolescents, it is up to the nurse to recognize them and nurture a nontraumatic and affectionate care. However, measures to control the disease affect the care provided. In this context, emotional labor process become essential, as they guide the management of the child's and family's emotions, associated with the suffering caused by the pandemic and the nurse's emotional experience when caring.

Conclusion: Emotional support and care processes are essential in pediatrics, especially in a stressful time such as a pandemic, which requires the positive transformation of the intense and disturbing experiences of people for them to achieve psychosocial well-being. Keywords: Pediatric nursing. Nursing care. Emotions. Coronavirus infections. Pandemics.

\section{RESUMO}

Objetivo: Refletir sobre o trabalho emocional em enfermagem pediátrica face às repercussões da COVID-19 na infância e adolescência. Método: Reflexão embasada em aspectos teóricos e evidências científicas do trabalho emocional em enfermagem pediátrica.

Resultados: Diante das repercussões da COVID-19 em crianças e adolescentes, cabe ao enfermeiro reconhecê-las e nutrir o cuidado não traumático e afetuoso. No entanto, observam-se implicações das medidas de controle da doença na forma de cuidar. Nesta conjuntura, o trabalho emocional torna-se essencial à medida que orienta a gestão das emoções da criança e família, associadas ao sofrimento causado pela pandemia e à experiência emocional do enfermeiro ao cuidar.

Conclusão: 0 trabalho emocional é imprescindível em pediatria, sobretudo em um momento estressante como 0 de pandemia, 0 qual requer a transformação positiva das vivências intensas e perturbadoras das pessoas em interação para o alcance do bem-estar psicossocial.

Palavras-chave: Enfermagem pediátrica. Cuidados de enfermagem. Emoções. Infecções por coronavírus. Pandemias.

\section{RESUMEN}

Objetivo: Reflexión sobre el trabajo emocional en enfermería pediátrica considerando las repercusiones de COVID-19 en infancia y adolescencia.

Método: Reflexión basada en aspectos teóricos y evidencia científica del trabajo emocional en enfermería pediátrica.

Resultados: Cabe a la enfermera reconocer las repercusiones de COVID-19 en niños y adolescentes, fomentando una atención no traumática y afectiva. Sin embargo, las medidas para controlar la enfermedad implican en la forma de la atención. En ese contexto, el trabajo emocional es esencial, ya que guía el manejo de las emociones de niños y de sus familias, asociadas al sufrimiento causado por la pandemia y a la experiencia emocional de la enfermera en el cuidado.

Conclusiones: El trabajo emocional es esencial en pediatría, especialmente en una situación estresante como la pandemia, que requiere la transformación positiva de las experiencias intensas y perturbadoras de las personas en interacción para lograr el bienestar psicosocial.

Palabras clave: Enfermería pediátrica. Atención de enfermería. Emociones. Infecciones por coronavirus. Pandemias. 


\section{IINTRODUCTION}

At the end of 2019, a disease caused by a new type of coronavirus - the severe acute respiratory syndrome by coronavirus 2 (SARS-CoV-2) - was identified in China and, in February 2020, was named COVID-19 by the World Health Organization $(\mathrm{WHO})^{(1)}$. Subsequently, the disease spread to other countries and the situation worsened further in mid-March 2020, after the detection of cases in Europe and America ${ }^{(2)}$, becoming the largest international public health emergency in decades ${ }^{(1)}$.

Most people infected by the virus have mild to moderate respiratory symptoms. Elderly people and those with previous chronic conditions are more likely to develop the severe form of the disease ${ }^{(1)}$. In children and adolescents, symptoms tend to be milder, such as fever and dry cough ${ }^{(2)}$, however, there is still little official data available on the number of symptomatic and asymptomatic individuals infected with COVID-19 in this age group.

Although children and adolescents are less susceptible than adults to the severe forms of COVID-19, it appears that, emotionally and psychologically, they have been strongly impacted by the pandemic, manifesting several behavioral problems ${ }^{(3)}$. Since the phenomenon is recent, its long-term effects on the mental and emotional health of these individuals are unknown. In this context, it is necessary offer them with emotional strength and effectively meet their needs, in order to reduce impairment.

Thus, pediatric nurses can act from the perspective of emotions in the context of the pandemic. This emotional care in pediatrics can be understood as the therapeutic intention of caring with affection and managing the emotions of the people being cared for, in addition to constituting a safe and affectionate environment, and a stable therapeutic relationship ${ }^{(4)}$.

Thus, supported by the framework of emotional labor in pediatric nursing ${ }^{(4)}$, this study sought to discuss its applicability in view of the repercussions of COVID-19 on children and adolescents. This framework, which emerged in sociology and was initially studied and applied to Nursing by Pam Smith ${ }^{(5)}$, is still little used by Brazilian nurses. Considering that one of the authors of this text was a pioneer in proposing a conceptual model of emotional labor in pediatrics and has expertise in its teaching and implementation in different areas of pediatric nurse practice in Portugal, this model was considered appropriate for the proposed reflection, aiming to recommend good practices in pediatric nursing care in this pandemic setting.
Thus, this reflexion was organized in three parts, namely: Emotional and behavioral repercussions of the COVID-19 pandemic in childhood and adolescence; Challenges to emotional care in pediatric nursing in the face of measures to control the pandemic of COVID-19; and Implementation of emotional labor in pediatric nursing in the context of the COVID-19 pandemic.

\section{EMOTIONAL AND BEHAVIORAL REPERCUSSIONS OF THE COVID-19 PANDEMIC IN CHILDHOOD AND ADOLESCENCE}

In the current situation, it is possible to glimpse at the emotional and behavioral repercussions of the COVID-19 pandemic in childhood and adolescence, since it is a potentially stressful event. These may be related to fear of infection, uncertainties regarding the disease, frustration, boredom, inadequate information, financial problems in the family, family grief and physical and social isolation, since schools are closed and children and adolescents are restricted to the home environment ${ }^{(3,6)}$. Even if the COVID-19 pandemic ends, its effects on mental and emotional health are broad, substantial, and can be long-lasting in this population.

The way in which parents inform their children about COVID-19 can increase their fear, in addition to the information received from the media, schoolmates, friends and other family members. Their contact with social media and alarming news can result in stress, anxiety and emotional insecurity ${ }^{(7)}$. This setting is aggravated by the spread of myths and false news about the disease, as well as by the difficulty of people in assimilating the guidelines of health authorities ${ }^{(8)}$.

Although physical distance measures are essential for the control of COVID-19, they can lead to some adversities, such as increased unemployment, salary cuts and a drop in the demand for informal services, which jeopardizes the family income, especially among those who need it more. In addition, the closure of daycare centers and schools has led to the suspension of school meals in the public school system, affecting the nutrition of the poorest children and adolescents nutrition and increasing household spending on food. These effects are an additional obstacle for some families, and these children and adolescents are the ones who can suffer the consequences the most ${ }^{(9)}$.

Away from school, daycare centers or routine activities (streets, gardens, parks, and other leisure spaces), they may feel powerless and uncomfortable, since they do not know when their daily activities will be back to normal. Without playgrounds and friends, they are prone to a state 
of frustration and boredom. Older children accept this circumstance more easily, as they have more maturity to understand and standardize their anxieties ${ }^{(7)}$. However, preschool children do not have the cognitive resources necessary to understand something as abstract as the new coronavirus and its consequences ${ }^{(9)}$, neither to manage such emotions.

Even in the early stages of the development of affectivity and intelligence - sensory-motor (up to approximately 2 years old) and symbolic or preoperative (2 to $7-8$ years old) stages - children are guided by experiences of what they can see, listen, touch, smell, imagine, imitate, say and play. Much more than understanding the concepts that explain such a situation, they are guided by the observation of their parents or family members and act according to the reactions of the people around them ${ }^{(9)}$. It is difficult for them to hide their feelings, just as it is costly for parents to manage their anxiety levels $s^{(7)}$.

Another relevant aspect is that many parents and caregivers are at home because they are unable to work, or trying to work remotely and still take care of the children, without clarity as to when this situation will end ${ }^{(10)}$ due to the unpredictability of the duration of the pandemic and its consequences ${ }^{(8)}$. Keeping them busy and safe at home is a cumbersome situation for many parents/caregivers, especially for those with low income ${ }^{(10)}$.

It is known that, for the growth and development of children and adolescents, the quality of family care is an extremely important factor and depends, above all, on adequate psychosocial, health and economic conditions. Precarious family contexts can promote risks to child and adolescent development. The coexistence of people under psychological stress in the same home can increase tension, situations of violence and toxic stress to this public. They absorb information from its context, developing an interaction with the environment. Thus, in a tense environment, they are expected to be sensitive and behave differently than usual(9).

A preliminary study conducted in the Chinese province of Shaanxi showed immediate effects of the COVID-19 pandemic on the psycho-emotional development of 320 participants between three and eighteen years of age, such as: distraction, irritability, fear of asking questions about the disease and wanting to be very close to family members. In addition, cases of insomnia, nightmares, lack of appetite, physical discomfort and agitation were observed. Children in the youngest age group (three to six years) manifested more often the symptom of wanting to be close to their parents and fearing that family members would be contaminated. Children older than six years, in turn, showed more distraction and doubt ${ }^{(3)}$.
Because children, especially preschoolers, do not understand the pandemic situation, they tend to react to the changes they perceive in the behavior of family members and their life routine. Thus, many of them sleep poorly, do not eat, cry, bite, show apathy or detachment. These are emotional responses to the adverse situation they are experiencing; manifestations of emotional discomfort and uneasiness. These reactions are also inefficient or poorly adaptive forms that impair their learning, development and family and social life processes ${ }^{(9)}$.

This situation also makes children and adolescents become less physically active, spend more time on screen activities (smartphones, tablets, television and others), have irregular sleep patterns and less favorable diets, which are harmful to their development. Such factors influence brain plasticity and, consequently, cognitive and emotional development ${ }^{(6,9)}$.

This situation becomes even more complex when they are separated from their families, because they are infected with the new coronavirus or are under suspicion, quarantined in hospitals or medical observation centers, or because their family members or caregivers are infected or died from the disease. These may be even more susceptible to mental suffering, due to the greater feeling of fear and anxiety caused by the loss or separation from family or caregivers ${ }^{(11)}$.

Also, for the children and adolescents with mental health problems prior to the pandemic, physical isolation means lack of access to the assistance resources that they usually have. When schools are closed, they lose their anchor in life and their symptoms may recur, given that school routines are important coping mechanisms. For those with depression, there will certainly be considerable difficulties in returning to daily activities when schools reopen. Those with autism spectrum disorder are also at risk, as they tend to be frustrated and irritated when their daily routines are interrupted ${ }^{(12)}$.

However, the emotional and behavioral implications of COVID-19 in childhood and adolescence have been little explored, since the pandemic is ongoing, and studies are still incipient. However, it is already known that this age group is socio-psycho-emotionally vulnerable, due to COVID-19 and its consequences. Therefore, it is necessary to be attentive and make efforts to effectively solve the emotional and behavioral problems identified, in order to avoid long-term consequences. In this context, to provide care in pediatrics, nurses need to understand these repercussions and overcome the challenges provoked by the control measures of the pandemic of COVID-19. 


\section{CHALLENGES TO EMOTIONAL CARE IN PEDIATRIC NURSING IN THE FACE OF MEASURES TO CONTROL THE PANDEMIC OF COVID-19}

Considering that the children and adolescents and their families are under multiple changes in their lives with emotional and behavioral repercussions due to the COVID-19 pandemic, the role of the nurse who takes care of them is crucial, since this professional values the emotional dimension of human care and complements the technical and scientific dimension.

Pediatric care involves flexibility and individuality, requiring attention to the expression of emotions and feelings of both the pediatric client targeted by the care and the nurses who care for them ${ }^{(4)}$. Thus, emotional care in pediatrics must contain affection, due to the importance of the therapeutic role of affectivity in nursing care. The concept of affection is related to the term love, and both refer to a feeling that is present in nursing care ${ }^{(13)}$.

Nurses need to pay attention to be able to nurture and enrich pediatric care with affection, imprinting it in every action or interaction with the client, helping them to manage their emotions. Therefore, it is essential for affectivity to be present in all care relationships, standing out as a constituent of the subjective dimension of emotional care ${ }^{(4)}$.

Thus, focused on interaction, one of the characteristics of nurses is that they understand the child and their family as unique beings, perceiving and identifying their feelings and emotions, recognizing their uniqueness in its entirety. In this context, caring is an exchange of love, an understanding of sadness and pain, it is letting the child or adolescent and family feel, with the approach and the necessary involvement for the actors to find meaning in the relationship, where emotions play a central role. In the care process, the nurse promotes and gives space for the release of the feelings and thoughts of the pediatric client and family, contributing to the acquisition of harmony and well-being ${ }^{(13)}$.

However, in the context of the COVID-19 pandemic, the children and adolescents are more vulnerable to feelings of anxiety, fear, sadness and loneliness, due to the isolation and withdrawal of family and friends, and even more in need of emotional care. This context also influences emotional care encounters due to the personal protective equipment used by nurses (gloves, mask, visor, and apron) and the physical distance imposed by infection control measures.

The emotional dimension of nursing care directed to the child and family is recognized in the Philosophy of Patient and Family-Centered Care, which recognizes the family as a constant in the lives of these subjects and whose central concepts are dignity and respect, information sharing, participation in care and collaboration ${ }^{(14)}$. However, pandemic control measures interfere with the implementation of this care philosophy, since the interaction between family, child and nurse is affected, due to the restriction of visits by family and friends during hospitalization. The family's decision-making in relation to pediatric care, as well as collaboration and negotiation in care planning, also changes, being a challenge for the maintenance of affective bonds.

In addition, the nurse, when using personal protective equipment, can be seen by the pediatric client as a threat, which generates insecurity and fear, and interferes with affection and emotional management during their interaction. In fact, in the face of this new reality imposed by the COVID-19 pandemic, the importance of nurses to develop emotional competence and be sensitive to provide non-traumatic care with affection in pediatrics is emphasized.

Maintaining a safe and affectionate and caring environment for the dyad ${ }^{(4)}$ becomes more challenging in the face of this situation. With regard to the safe and affectionate environment, the act of greeting and the expressions of affection on the part of nurses to the children can be more difficult to observe, as well as the sharing of toys, since the preventive measures of the pandemic require the frequent washing and disinfection of toys and the closing of toy libraries. The relationship between nurses, pediatric clients and parents may be more distant and with less physical contact, but emotional closeness can be maintained and even increased through the implementation of emotional labor by pediatric nurses.

\section{IMPLEMENTATION OF EMOTIONAL LABOR IN PEDIATRIC NURSING IN THE CONTEXT OF THE COVID-19 PANDEMIC}

The concept of emotional labor was first described in the field of sociology, and in the nursing area it was based on the pioneering investigation of Pam Smith ${ }^{(5)}$. The author defines emotional labor as the act or the skills involved in caring for and recognizing the emotions of others, and not only the emotions experienced by nurses. Nurses regulate their emotions to positively influence the management of emotional responses of the pediatric client and the family they care for, and to provide nursing care ${ }^{(4)}$.

The emotional labor in nursing aims to equip and strengthen these professionals with knowledge that will help them face and manage the emotional challenges intrinsic to the act of caring ${ }^{(5)}$, especially in the context of COVID-19. In addition, there are components of the nurse's 
emotional labor, such as providing support and tranquility, tenderness, kindness, sympathy, empathy, being uplifting, using humor, being patient, relieving suffering, knowing the client and helping to solve problems, as well as suppressing the expression of inappropriate emotions ${ }^{(5)}$.

The intentional use of emotions in the act of caring positively transforms the experience, relationships and the care. It promotes relief from suffering and improves the well-being and growth of the people involved (pediatric client, family and nurses) ${ }^{(4)}$. Therefore, the emotional labor may bring benefits for pediatric clients, their families, the nurse, and for the relationship among this triad, in this atypical experience during COVID-19

In order to positively manage and overcome the misfortunes imposed by COVID-19, it is recommended for the Emotional Labor Model in Pediatric Nursing ${ }^{(4)}$ to be implemented by these professionals in health services, which present interventions with an affective-emotional dimension when caring for pediatrics. This model consists of five components expressed due to their therapeutic intent: to promote a warm and affectionate environment; promote care with affection; facilitate the management of the emotions of clients; build relationship stability; and regulate the emotional disposition of the nurses. Thus, nurses manage the emotions of the dyad, the suffering inherent in the health-disease processes and their own emotional experience of caring ${ }^{(4,15)}$.

Nurses are faced with difficult situations to deal with emotionally, such as the loss of professional colleagues victimized by COVID-19, the fear of being contaminated and of contaminating their family members, which leads to a need for an emotional disposition to care for the pediatric client, through intentional regulation. The feeling of gratitude of the pediatric client, the support among colleagues, the sharing of feelings, the feeling of accomplishment, reading, writing, faith, and the momentary distancing from interactions with the client, to recover from the emotional impact, are some effective and resilient emotional regulation strategies to be used by nurses.

In the face of this pandemic setting, the emotional competence of nurses becomes even more crucial, and should be promoted through academic and professional training provided by health institutions. Therefore, some training strategies are discussed for the development of emotional competence and performance in nurses' emotional labor processes, namely the analysis of practices in the workplace with experienced nurses, reflective learning, the training of client-centered emotional competence and the knowledge about one's own emotions, as well as group dynamics with emotional management exercises ${ }^{(4)}$.

Other strategies that may be added are the promotion of forums for scientific debate on the meaning of emotions in health care, expressive-projective activities (conversation circles, dramatization, group dynamics, emotional management exercises, among others) or workshops on the emotional labor in pediatric nursing, and team building/ consolidation activities ${ }^{(4)}$.

It is about investing in personal development and in a reflective nursing practice, which leads to greater personal knowledge and, as such, to a positive influence on the care relationship. Nurses, during their care practice, implement specific procedures appropriate to the circumstances of care they live in, like caring for the pediatric client in a pandemic situation, with the purpose of obtaining therapeutic results. This allows for the transformation of disturbing emotional phenomena into restorative and adaptive states or emotions, leading to the well-being and satisfaction of the interacting triad ${ }^{(4,15)}$.

The nurse plays a decisive role in the emotional management of the pediatric client, through the use of creative communication techniques, both when playing and interacting with the child, as well as when making it possible for them to communicate with their families, for example, with the use of video via smartphones or computers and even through the encouragement of free drawing. In this way, the nurse promotes the maintenance of the family affective bond, which is fundamental for the development of children and adolescents. These strategies are essential in the care relationship, aiming to create affective and welcoming environments for the child and family; to facilitate the management of the pediatric client's emotions, by providing the expression of the processes of feeling, in addition to involving personal skills to deal adaptively with the emotional world; and manage one's own emotions and relationships ${ }^{(4)}$.

Thus, the investment of nurses in affective involvement with the pediatric client is paramount. Affection can be manifested by a gentle voice, a tender look, welcoming verbal expressions, empathy, positive reinforcement and gesture expressions of sympathy, gentleness, kindness and joy, in order to minimize the effects of the pandemic. There are also games, which may include word and number games, mime, telling stories or fables, singing, talking about subjects according to the development stage of the child and the parent/caregiver affection, as strategies to facilitate the emotional management of child. 


\section{Q CONCLUSION}

From the reflexions presented, it can be concluded that COVID-19 and its consequences have had relevant emotional and behavioral impacts on the child and adolescent population, on nurses, and also on the pediatric care process. Children and adolescents may be emotionally vulnerable in the current context and, therefore, it is necessary to pay attention to the signs of emotional and behavioral problems, and to undertake emotional labor in order to avoid long-term consequences of their development.

The pandemic implies a disturbing emotional experience, both for the person being cared for and for the nurse who provides the care. In this context, the Emotional Labor Model in Pediatric Nursing is seen to have great therapeutic value, since it guides positive transformations of experiences, relationship, and nursing care. It guides the promotion of a safe and affectionate environment, the emotional regulation of nurses, and the management of the emotional state of children, adolescents and their families. Thus, it is possible to ensure the stability of relationships, alleviate suffering and promote a more positive and resilient experience for those involved.

\section{REFERENCES}

1. World Health Organization (CH). Geneva: WHO; c2020 [cited 2020 May 21]. Coronavirus disease (COVID-19) pandemic; [about 1 screen]. Available from: https://www.who.int/emergencies/diseases/novel-coronavirus-2019

2. Jeng M. Coronavirus disease 2019 in children: current status. J Chin Med Assoc. 2020;83(6):527-33. doi: https://doi.org/10.1097/ JCMA.0000000000000323

3. Jiao WY, Wang LN, Liu J, Fang SF, Jiao FY, Pettoello-Mantovani $M$, et al. Behavioral and emotional disorders in children during the COVID-19 epidemic. J Pediatr. 2020;221:264-6. doi: https://doi.org/10.1016/j.jpeds.2020.03.013
4. Diogo PMJ. Trabalho com emoções em enfermagem pediátrica - um processo de metamorfose da experiência emocional no ato de cuidar. $2^{\text {a }}$ Ed. Loures: Lusodidacta; 2015.

5. Smith P. Emotional labour of nursing revisited: can nurses still care? $2^{\text {nd }}$ ed. Hampshire: Palgrave Macmillan; 2012.

6. Wang G,ZhangY,Zhao J,ZhangJ,Jiang F.Mitigatetheeffects of homeconfinement on children during the COVID-19 outbreak. Lancet. 2020;395(10228):945-7. doi: https://doi.org/10.1016/S0140-6736(20)30547-X

7. Saxena R, Saxena SK. Preparing children for pandemics. In: Saxena SK, editor. Coronavirus disease 2019 (COVID-19): epidemiology, pathogenesis, diagnosis, and therapeutics. Singapore: Springer Nature Singapore; 2020. p. 187-98. doi: https://doi.org/10.1007/978-981-15-4814-7

8. Schmidt B, Crepaldi MA, Bolze SDA, Neiva-Silva L, Demenech LM. Saúde mental e intervenções psicológicas diante da pandemia do novo coronavírus (COVID-19). Estud Psicol. 2020;37:e200063. doi: https://doi. org/10.1590/1982-0275202037e200063

9. Núcleo Ciência pela Infância (BR). Repercussões da pandemia de Covid-19 no desenvolvimento infantil: working paper [Internet]. Edição especial. São Paulo: NCPI; 2020 [cited 2020 May 21]. Available from: https://ncpi.org.br/ wp-content/uploads/2020/05/Working-Paper-Repercussoes-da-pandemiano-desenvolvimento-infantil-3.pdf

10. Cluver L, Lachman JM, Sherr L, Wessels I, Krug E, Rakotomalala S, et al. Parenting in a time of COVID-19. Lancet. 2020;395(10231):e64. doi: https:// doi.org/10.1016/S0140-6736(20)30736-4

11. Liu J, Bao Y, Huang X, Shi J, Lu L. Mental health considerations for children quarantined because of COVID-19. Lancet Child Adolesc Health. 2020;4(5):3479. doi: https://doi.org/10.1016/S2352-4642(20)30096-1

12. Lee J. Mental health effects of school closures during COVID-19. Lancet Child Adolesc Health. 2020;4(6):421. doi: https://doi.org/10.1016/ S2352-4642(20)30109-7

13. Watson J. Human caring science: a theory of nursing. 2nd edition. London: Jones and Bartlett Learning; 2012.

14. Sanders, J. Cuidados centrados na família em situações de doença e hospitalização. In: Hockenberry M, Wilson D, editors. Wong: enfermagem da criança e adolescente. 9. a ed. Loures: Lusociência; 2014. p.1025-57.

15. Vilelas JMS, Diogo PMJ. Emotional labor in nursing praxis. Rev Gaúcha Enferm. 2014;35(3):145-49. doi: https://doi.org/10.1590/1983-1447.2014.03.45784 
- Acknowledgments:

To the Research and the Graduation departments of the Federal University of Mato Grosso for supporting the publication.

\section{- Authors contributions:}

Conceptualization: Bruna Hinnah Borges Martins de Freitas, Ana Inês Lourenço da Costa, Paula Manuela Jorge Diogo and Maria Aparecida Munhoz Gaíva.

Formal analysis: Bruna Hinnah Borges Martins de Freitas, Ana Inês Lourenço da Costa, Paula Manuela Jorge Diogo and Maria Aparecida Munhoz Gaíva.

Acquisition of financing: Bruna Hinnah Borges Martins de Freitas.

Data collection: Bruna Hinnah Borges Martins de Freitas and Ana Inês Lourenço da Costa.

Methodology: Bruna Hinnah Borges Martins de Freitas, Ana Inês Lourenço da Costa, Paula Manuela Jorge Diogo and Maria Aparecida Munhoz Gaíva.

Supervision: Paula Manuela Jorge Diogo and Maria Aparecida Munhoz Gaíva.

Writing - original draft: Bruna Hinnah Borges Martins de Freitas and Ana Inês Lourenço da Costa.

Writing - review and editing: Paula Manuela Jorge Diogo and Maria Aparecida Munhoz Gaíva.

\section{- Corresponding author:}

Bruna Hinnah Borges Martins de Freitas

Email: bruhinnah@gmail.com

\section{Associate editor:}

Dagmar Elaine Kaiser 